\title{
Analisis Terhadap Putusan Yang Menjatuhkan Sanksi Pidana Di Bawah Ancaman Minimal (Studi Putusan Nomor: 284/Pid.Sus/2017/PN.Kka)
}

\author{
Analysis of Decisions Dropping Criminal Sanctions Under Minimal \\ Threats (Study of Decision Number: 284/Pid.Sus/2017/PN.Kka)
}

\author{
Abdul Rahman \\ Universitas Halu Oleo \\ E-mail: abdulrahmanrahman245@gmail.com \\ Sabrina Hidayat \\ Pascasarjana Universitas Halu Oleo \\ E-mail: sabrina.hidayat54@yahoo.com \\ Handrawan \\ Pascasarjana Universitas Halu Oleo \\ E-mail: handrawansaranani84@gmail.com
}

\begin{abstract}
This study aims to analyze the imposition of criminal sanctions by judges against the perpetrators of molestation of minors and to determine the legal considerations by judges in imposing criminal sanctions against perpetrators of child molestation in decision number 284/Pid.Sus/2017/PN.Kka. This research was carried out in Kolaka Regency by selecting the agency related to this case, namely the Kolaka District Court. the technique of gathering legal material is by searching cases, laws and regulations and studying literature, then analyzed qualitatively so as to reveal the expected results and conclusions on the problem. The results showed that the imposition of criminal sanctions by the Kolaka District Court judge was not in accordance with the minimum limit stipulated in Law Number 35 of 2014, so that the judge's decision was contrary to statutory regulations. In addition, legal considerations by judges in imposing sanctions on child criminal offenses is in this case the defendant and the victim committed sexual intercourse on the basis of like and like while in the explanation of the law above, it does not regulate the imposition of criminal sanctions specifically on the basis of like and liking. Another consideration is the Circular of the Supreme Court of the Republic of Indonesia Number 1 of 2017 as a guideline for the implementation of duties for the court. On the fifth point concerning minimal criminal imprisonment against child and adult offenders, then if the perpetrator is an adult while the victim is a child, judging by casuistically, the panel of judges can drop the criminal below the minimum with
\end{abstract}


special consideration that there is peace and the re-creation of harmonizing relations between the perpetrator/the family of the perpetrator with the victim/the victim's family by not demanding each other anymore.

Keywords: Criminal Sanctions; Minimal Threats; Molestation

\begin{abstract}
Abstrak: Penelitian ini bertujuan untuk menganalisis penjatuhan sanksi pidana oleh hakim terhadap pelaku pencabulan anak di bawah umur dan untuk mengetahui pertimbangan hukum oleh hakim dalam menjatuhkan sanksi pidana terhadap pelaku tindak pencabulan anak pada putusan nomor 284/Pid.Sus/2017/PN.Kka. penelitian ini dilaksanakan di Kabupaten Kolaka dengan memilih instansi yang terkait dengan perkara ini yakni di Pengadilan Negeri Kolaka. teknik pengumpulan bahan hukum adalah dengan cara telusur perkara, peraturan perundang-undangan dan studi kepustakaan, kemudian dianalisis secara kualitatif sehingga mengungkapkan hasil yang diharapkan dan kesimpulan atas permasalahan. Hasil penelitian menunjukkan bahwa penjatuhan sanksi pidana oleh hakim Pengadilan Negeri Kolaka tidak sesuai dengan ketentuan batas minimum yang telah ditentukan di dalam Undang-Undang Republik Indonesia Nomor 35 Tahun 2014 tentang Perubahan Atas Undang-Undang Nomor 23 Tahun 2002 Tentang Perlindungan Anak, sehingga putusan hakim bertentangan dengan peraturan perundangundangan. Selain itu, pertimbangan hukum oleh hakim dalam menjatuhkan sanksi terhadap pelaku pidana anak adalah dalam kasus ini terdakwa dan korban melakukan persetubuhan atas dasar suka sama suka sementara dalam penjelasan undang-undang di atas, tidak mengatur penjatuhan sanksi pidana terkhusus kasus atas dasar suka sama suka. pertimbangan lainnya adalah adanya Surat Edaran Mahkamah Agung Republik Indonesia Nomor 1 Tahun 2017, tentang pemberlakuan rumusan hasil Rapat Pleno Kamar Mahkamah Agung Tahun 2017 sebagai pedoman pelaksanaan tugas bagi pengadilan. Pada poin kelima tentang penjatuhan pidana minimal terhadap pelaku anak dan orang dewasa, maka apabila pelakunya sudah dewasa sedangkan korbannya adalah anak, dilihat secara kasuistik, majelis hakim dapat menjatuhkan pidana di bawah minimal dengan pertimbangan khusus yaitu ada perdamaian dan terciptanya kembali harmonisasi hubungan antara pelaku/keluarga pelaku dengan korban/keluarga korban dengan tidak saling menuntut lagi.
\end{abstract}

Kata kunci: Sanksi Pidana; Ancaman Minimal; Pencabulan

\title{
PENDAHULUAN
}

Indonesia adalah Negara yang berdasarkan atas hukum, sehingga setiap kegiatan manusia atau masyarakat yang merupakan aktivitas hidupnya harus berdasarkan peraturan yang ada dan norma-norma yang berlaku dalam masyarakat. Hukum tidak lepas dari kehidupan manusia karena hukum merupakan aturan untuk mengatur tingkah laku manusia dalam kehidupannya karena tanpa adanya hukum tidak dapat dibayangkan akan seperti apa nantinya negara ini. Kejahatan terus bertambah dengan cara yang berbeda-beda bahkan 
dengan peralatan yang semakin canggih dan modern sehingga kejahatan akan semakin meresahkan masyarakat.

Pencabulan merupakan suatu tindak kejahatan yang sangat keji, amoral, tercela dan melanggar norma dimana yang menjadi korban adalah perempuan baik dewasa maupun anak di bawah umur. Pencabulan termasuk dalam penggolongan jenis tindak pidana kesusilaan dimana hal tersebut diatur dalam Kitab Undang-Undang Hukum Pidana (KUHP) Pasal 290 Nomor 2 dan 3. ${ }^{1}$ Selain dalam KUHP yang berkaitan dengan kekerasan seksual (Pencabulan) terhadap anak terdapat dalam Undang-Undang Nomor 35 Tahun 2014 tentang Perubahan Undang-Undang Nomor 23 Tahun 2002. Pada Pasal 82 ayat (1) menyatakan:2 "Setiap orang yang melanggar ketentuan sebagaimana dimaksud dalam Pasal 76E dipidana dengan pidana penjara paling singkat 5 (lima) tahun dan paling lama 15 (lima belas) tahun dan denda paling banyak Rp5.000.000.000,00 (lima miliar rupiah)". Pasal 82 ayat (2): "Dalam hal tindak pidana sebagaimana dimaksud pada ayat (1) dilakukan oleh Orang Tua, Wali, pengasuh Anak, pendidik, atau tenaga kependidikan, maka pidananya ditambah $1 / 3$ (sepertiga) dari ancaman pidana sebagaimana dimaksud pada ayat (1)." Menurut Pasal 76E "Setiap Orang dilarang melakukan Kekerasan atau ancaman Kekerasan, memaksa, melakukan tipu muslihat, melakukan serangkaian kebohongan, atau membujuk Anak untuk melakukan atau membiarkan dilakukan perbuatan cabul."

Pertimbangan hakim juga menentukan berat ataupun ringannya pemidanaan, karena sering kali persoalan yang dilontarkan masyarakat adalah terlalu ringannya pidana, jadi adanya keyakinan hakim dalam menentukan berat ataupun ringannya dalam suatu putusan penting untuk diselidiki. Kemudian apakah kemandirian kekuasaan kehakiman mempunyai implikasi terhadap penegakan hukum oleh hakim di muka persidangan. Sudah jelas implikasinya besar karena sikap hakim dalam proses peradilan akan sangat menentukan obyektivitas dalam memutuskan suatu perkara. Bahkan Sahlan

1 Pasal 290 Nomor 2 dan 3 Kitab Undang-Undang Hukum Pidana berbunyi:

Pasal 290 Diancam dengan pidana penjara paling lama tujuh tahun: 2. barang siapa melakukan perbuatan cabul dengan seorang padahal diketahuinya atau sepatutnya harus diduganya, bahwa umumnya belum lima belas tahun atau kalau umurnya tidak jelas, yang bersangkutan belum waktunya untuk dikawin; 3 . barang siapa membujuk seseorang yang diketahuinya atau sepatutnya harus diduganya bahwa umurnya belum lima belas tahun atau kalau umurnya tidak jelas yang bersangkutan belum waktunya untuk dikawin, untuk melakukan atau membiarkan dilakukan perbuatan cabul, atau bersetubuh di luar perkawinan dengan orang lain.

2 Undang-Undang Republik Indonesia Nomor 35 Tahun 2014 tentang Perubahan Atas Undang-Undang Nomor 23 Tahun 2002 Tentang Perlindungan Anak (Lembaran Negara Republik Indonesia Tahun 2014 Nomor 297, Tambahan Lembaran Negara Republik Indonesia Nomor 5606) 
Said, seorang hakim senior dari Pengadilan Negeri Malang dalam tulisannya menyatakan bahwa satu-satunya jabatan atau profesi yang dapat mewakili tuhan kiranya adalah hanya hakim, sebab otoritas yang diberikan kepadanya buka sekedar memenjara tapi juga dapat mencabut nyawa seseorang. Beberapa ungkapan yang memberikan kedudukan istimewa kepada hakim misalnya, adalah benteng terakhir bagi pencari keadilan, selain itu hakim juga merupakan ultimum remedium yang menjadi senjata pamungkas bagi semua ketidakberesan, karena itu ada ungkapan yang cukup ekstrem bahwa semua bagian masyarakat boleh rusak asalkan hakimnya semuanya akan menjadi beres ${ }^{3}$

Tindak pidana pencabulan dalam hal ini adanya pelaksanaan Penerapan Hukum atau Penjatuhan Sanksi kepada para pelaku pencabulan anak tidak sesuai dengan ketentuan Undang-Undang. Salah satu putusan kasus pencabulan yang terjadi di Kabupaten Kolaka, yakni Putusan Nomor 284/Pid.Sus/2017/PN.Kka. Hakim Pengadilan Negeri Kolaka mengadili pelaku Tindak Pidana Pencabulan dan menjatuhkan pidana penjara selama 2 (dua) tahun, dan pidana denda sejumlah Rp. 50.000.000,- (lima puluh juta rupiah) dengan Putusan tersebut, hal ini tidak sesuai dengan ketentuan sanksi pidana yang terdapat dalam Undang-Undang Nomor 35 Tahun 2014 atas perubahan UndangUndang Nomor 23 Tahun 2002 tentang Perlindungan Anak, khususnya pada Pasal 82 ayat (1) berbunyi "Setiap orang yang melanggar ketentuan sebagaimana dimaksud dalam Pasal 76e dipidana dengan pidana penjara paling singkat 5 (lima) tahun dan paling lama 15 (lima belas) tahun dan denda paling banyak Rp.5.000.000.000.00 (lima miliar rupiah)”.

\section{METODE PENELITIAN}

Dalam penelitian tentang Analisis Terhadap Putusan Yang Menjatuhkan Sanksi Pidana Di Bawah Ancaman Minimal ini menggunakan jenis penelitian hukum normatif. Penelitian Hukum Normatif merupakan penelitian yang mengkaji studi dokumen, yakni menggunakan data sekunder seperti peraturan perundang-undangan, putusan pengadilan, teori hukum, dan dapat berupa pendapat para sarjana. Dalam penelitian tentunya memerlukan bahan hukum. Menurut Peter Mahmud Marzuki penelitian hukum normatif adalah suatu proses untuk menemukan sebuah aturan, prinsip-prinsip hukum , maupun doktrin-doktrin hukum untuk menjawab permasalahan hukum yang di hadapi. ${ }^{4}$

\footnotetext{
3 Bambang Sutiyoso, Sri Hastuti Puspitasari, “Aspek-Aspek Perkembangan Kekuasaan Kehakiman di Indonesia", dikutip dari Sahlan Said, Kemandirian Kekuasaan Kehakiman Pengalaman Praktek Menuju Kemandirian Hakim Tolak Ukur Dan Kendalanya, Seminar 50 Tahun Kemandirian Kekuasaan Kehakiman Di Indonesia Di Universitas Gadjah Mada Tanggal 26 Agustus 1995, Yogyakarta: UII Press, 2005, hlm. 87.

4 Peter Mahmud Marzuki, Penelitian Hukum, Jakarta: Kencana, 2008, hlm. 35.
} 
Penelitian hukum normatif dilakukan untuk menghasilkan argumentasi, teori atau konsep baru sebagai gambaran dalam menyelesaikan masalah yang di hadapi. ${ }^{5}$

\section{ANALISIS DAN PEMBAHASAN}

\section{Penjatuhan Sanksi Pidana Terhadap Pelaku Tindak Pidana Anak Pada Putusan Nomor 284/Pid.Sus/2017/PN.Kka}

Pengadilan Negeri Kolaka yang mengadili perkara pidana dengan Putusan Nomor 284/Pid.Sus/2017/PN.Kka Majelis Hakim menjatuhkan Putusan kepada Terdakwa:

1. Menyatakan terdakwa tidak terbukti secara sah dan meyakinkan bersalah melakukan tindak pidana "Dengan kekerasan memaksa anak bersetubuh dengannya"

2. Membebaskan terdakwa dari dakwaan kesatu Primer.

3. Menyatakan terdakwa terbukti secara sah dan meyakinkan bersalah melakukan tindak pidana "membujuk Anak bersetubuh dengannya"

4. Menjatuhkan Pidana kepada terdakwa dengan Pidana penjara selama 2 (Dua) tahun dan denda sejumlah Rp.50.000.000,- (Lima puluh juta rupiah) dengan ketentuan apabila denda tersebut tidak dibayar diganti dengan Pidana kurungan selama 3 (tiga) bulan.

Terkait penjatuhan sanksi Pidana Pelaku Tindak pidana Pencabulan, UndangUndang Perlindungan Anak (UUPA) dalam konsiderans tentang perlindungan anak menyebutkan agar setiap anak kelak dapat memikul tanggung jawab, dalam penjatuhan sanksi pidana perkara anak seharusnya mengedepankan proses di luar peradilan dengan melibatkan pelaku, korban, keluarga pelaku/korban. Dan pihak lain yang terkait untuk bersama-sama untuk mencari penyelesaian yang adil dengan menekankan pemulihan kembali pada keadaan semula dan bukan pembalasan untuk mencari keadilan restorative, melainkan pelaku dan korban atas perbuatan tersebut dapat di pertanggungjawabkan dengan seksama. Bila dikaitkan dengan restorative justice dalam penyelesaian perkara anak yang sedang berhadapan dengan hukum, telah lebih dahulu mengenal istilah penyelesaian sengketa tanpa harus diselesaikan di meja pengadilan. Berbagai upaya yang dilakukan untuk menemukan jalan damai dari pihak pelaku dan korban yang mana dengan ini bisa dijadikan sebagai landasan sosiologis untuk penerapan diversi itu sendiri.

Tidak mudah bagi hakim untuk membuat suatu putusan terhadap setiap perkara yang ditanganinya, tidak terkecuali dalam memutuskan tindak pidana asusila terhadap anak. Hal ini sebagaimana yang pendapat dari Gustav Radbruch yang dikutip oleh Sudikno

5 Yulianto Ahmad \& Mukti Fajar, Dualisme Penelitian Hukum Normatif \& Empiris, Yogyakarta: Pustaka Pelajar, 2010, hlm. 48. 
Mertokusumo yang menyebutkan bahwa "idealnya putusan harus memuat 3 (tiga) unsur, yaitu: keadilan, kepastian hukum dan kemanfaatan". 6 "Ketiga unsur tersebut semestinya oleh hakim harus dipertimbangkan dan diterapkan secara proporsional sehingga pada akhirnya dapat dihasilkan putusan yang berkualitas dan memenuhi harapan bagi para pencari keadilan"7. Pemidanaan berarti "terdakwa dijatuhi hukuman pidana sesuai dengan ancaman yang ditentukan dalam pasal tindak pidana yang didakwakan kepada terdakwa". ${ }^{8}$

Berkaitan dengan penjatuhan pidana terhadap pelaku Pencabulan terhadap anak apabila dikaitkan dengan penjatuhan pidana di bawah batas minimal dari ketentuan Undang-Undang Perlindungan Anak sebagaimana yang dilakukan oleh Hakim di Pengadilan Negeri Kolaka, terlihat bahwa hakim tidak memosisikan dirinya sebagai corong undang-undang. Hal ini dikarenakan putusan yang dijatuhkan tidak sesuai dengan ketentuan Batas Minimal yang telah diatur dalam Undang-Undang Republik Indonesia Nomor 35 Tahun 2014 tentang Perubahan Atas Undang-Undang Nomor 23 Tahun 2002 Tentang Perlindungan Anak.

\section{Pertimbangan Hukum Hakim Dalam Menjatuhkan Sanksi Pidana Terhadap Pelaku Tindak Pidana Pencabulan Anak Pada Putusan Nomor 284/PID.SUS/2017/PN.Kka}

Pertimbangan hakim dalam menjatuhkan Pidana terhadap terdakwa selama 2 Tahun tersebut tidak sesuai dengan ketentuan minimum yang telah diatur dalam ketentuan Undang-Undang Republik Indonesia Nomor 35 Tahun 2014 tentang Perubahan Atas Undang-Undang Nomor 23 Tahun 2002 Tentang Perlindungan Anak, Khususnya pasal 81 yakni Pidana Penjara paling singkat 5 (lima) tahun. Dan paling lama 15 (lima belas) Tahun. Hakim mempunyai pandangan bahwa Undang-Undang Nomor 35 Tahun 2014 tidak menjelaskan Penjatuhan sanksi Pidana terkhusus kasus suka sama suka.

Menurut penulis, pertimbangan majelis hakim dalam menjatuhkan sanksi pidana pada perkara nomor 284/Pid.Sus/2017/PN.Kka) adalah majelis Hakim menilai bahwa untuk menjatuhkan Pidana kepada terdakwa haruslah berdasarkan kualitas perbuatan, motif perbuatan, akibat yang ditimbulkan dari perbuatan tersebut dan harapan kedua belah pihak atas terjadinya peristiwa pidana.

6 Sudikno Mertokusumo, Mengenal Hukum Suatu Pengantar, Yogyakarta: Liberty, 1996, hlm. 15.

7 Bambang Sutiyoso, Metode Penemuan Hukum: Upaya Mewujudkan Hukum yang Pasti dan Berkeadilan, Cet. 2, Yogyakarta: UII Press, 2006, hlm. 6.

8 M. Yahya Harahap, Pembahasan Permasalahan dan Penerapan KUHAP: Pemerikasaan Sidang Pengadilan, Banding, Kasasi, dan Peninjauan Kembali, Edisi Kedua, Jakarta: Sinar Grafika, 2008, hlm. 354. 
Berdasarkan Surat Edaran Mahkamah Agung Republik Indonesia Nomor 1 Tahun 2017 tentang Pemberlakuan Rumusan Hasil Rapat Pleno Kamar Mahkamah Agung Tahun 2017 sebagai pedoman pelaksanaan tugas bagi pengadilan. Pleno Kamar melahirkan rumusan-rumusan sebagai berikut:

1. Rumusan pleno kamar Pidana;

2. Rumusan pleno kamar Perdata;

3. Rumusan pleno kamar agama;

4. Rumusan pleno kamar militer;

5. Rumusan pleno kamar tata usaha negara;

6. Rumusan pleno kamar kesekretariatan.

Dalam rumusan pleno kamar pidana pada poin kelima tentang penjatuhan pidana Minimal terhadap pelaku tindak Pidana Anak dan Orang dewasa tetapi korbannya adalah Anak, bahwa apabila pelakunya sudah dewasa sedangkan korbannya adalah Anak, Maka dilihat secara Kasuistik, Majelis Hakim dapat menjatuhkan pidana di bawah Minimal dengan pertimbangan khusus antara lain:

1. Ada perdamaian dan terciptanya kembali harmonisasi hubungan antara pelaku/keluarga pelaku dengan korban/keluarga korban, dengan tidak saling menuntut lagi bahkan sudah menikah antara pelaku dan korban, atau perbuatan dilakukan suka sama suka.

2. Harus ada pertimbangan hukum dilihat dari aspek yuridis, filosofis, Sosiologis, Edukatif, Preventif, Korektif, Represif, dan rasa keadilan.

Dengan adanya Surat Edaran Mahkamah Agung Nomor 1 Tahun 2017, Maka Majelis Hakim dapat menjadikan dasar pertimbangan untuk menjatuhkan putusan perkara pidana anak pada Putusan Nomor 284/Pid.Sus/2017/PN.Kka.

\section{KESIMPULAN}

Berdasarkan pada uraian pembahasan yang telah dikemukakan di atas, penulis dapat simpulkan bahwa Penjatuhan Pidana oleh Hakim Pengadilan Negeri Kolaka dengan putusan pidana 2 (dua) Tahun penjara dan denda sebesar Rp 50.000.000,- (lima puluh juta rupiah), subsider pidana kurungan 3 (tiga) bulan sebagaimana yang diatur dalam ketentuan Undang-Undang Perlindungan Anak, lebih ringan dari tuntutan Jaksa Penuntut Umum yakni 10 (sepuluh) Tahun Penjara. Dengan putusan tersebut Hakim menjatuhkan Pidana kepada terdakwa, tidak sesuai dengan ketentuan batas Minimum yang diatur 
dalam Pasal 81 Undang-Undang Republik Indonesia Nomor 35 Tahun 2014 tentang Perubahan Atas Undang-Undang Nomor 23 Tahun 2002 Tentang Perlindungan Anak yakni Pidana penjara paling singkat 5 (lima) Tahun dan Paling lama 15 (lima belas) Tahun dan Denda paling banyak Rp. 5.000.000.000,00 (Lima Miliar rupiah). Sehingga Putusan Hakim bertentangan dengan ketentuan peraturan perundang-undangan dan adapun Pertimbangan Hukum oleh Hakim dalam menjatuhkan sanksi terhadap Pelaku Pidana Anak pada Putusan Nomor 284/Pid.Sus/2017/PN.Kka adalah dalam kasus ini terdakwa dan korban melakukan persetubuhan atas dasar suka sama suka sementara dalam penjelasan Undang-Undang Republik Indonesia Nomor 35 Tahun 2014 tentang Perubahan Atas Undang-Undang Nomor 23 Tahun 2002 Tentang Perlindungan Anak, tidak mengatur penjatuhan sanksi pidana terkhusus kasus atas dasar suka sama suka. Pertimbangan lainnya adalah adanya Surat Edaran Mahkamah Agung Republik Indonesia Nomor 1 Tahun 2017,Tentang pemberlakuan rumusan hasil rapat pleno kamar Mahkamah Agung Tahun 2017 sebagai pedoman pelaksanaan tugas bagi pengadilan. Berdasarkan rumusan pleno kamar pidana pada poin kelima tentang Penjatuhan Pidana Minimal terhadap Pelaku Pidana Anak dan Orang dewasa, Tetapi korbannya adalah Anak, Maka apabila pelakunya sudah dewasa sedangkan korbannya adalah Anak, Dilihat secara kasuistik, Majelis Hakim dapat menjatuhkan Pidana di bawah minimal dengan Pertimbangan Khusus yaitu ada perdamaian dan terciptanya kembali harmonisasi hubungan antara Pelaku/Keluarga pelaku dengan Korban/Keluarga Korban dengan tidak saling menuntut lagi, bahkan sudah menikah antara pelaku dan korban, atau perbuatan dilakukan suka sama suka.

\section{Daftar Pustaka}

\section{Buku}

Ahmad, Yulianto \& Mukti Fajar, Dualisme Penelitian Hukum Normatif \& Empiris, Yogyakarta: Pustaka Pelajar, 2010.

Harahap, M. Yahya, Pembahasan Permasalahan dan Penerapan KUHAP: Pemerikasaan Sidang Pengadilan, Banding, Kasasi, dan Peninjauan Kembali, Edisi Kedua, Jakarta: Sinar Grafika, 2008.

Marzuki, Peter Mahmud, Penelitian Hukum, Jakarta: Kencana, 2008.

Mertokusumo, Sudikno, Mengenal Hukum Suatu Pengantar, Yogyakarta: Liberty, 1996.

Said, Sahlan, Kemandirian Kekuasaan Kehakiman Pengalaman Praktek Menuju

Kemandirian Hakim Tolak Ukur Dan Kendalanya, Seminar 50 Tahun Kemandirian 
Kekuasaan Kehakiman Di Indonesia Di Universitas Gadjah Mada Tanggal 26 Agustus 1995, Yogyakarta: UII Press, 2005.

Sutiyoso, Bambang, Metode Penemuan Hukum: Upaya Mewujudkan Hukum yang Pasti dan Berkeadilan, Cet. 2, Yogyakarta: UII Press, 2006.

\section{Peraturan Perundang-undangan}

Undang-Undang Dasar Negara Republik Indonesia Tahun 1945.

Kitab Undang-Undang Hukum Pidana.

Undang-Undang Republik Indonesia Nomor 35 Tahun 2014 tentang Perubahan Atas Undang-Undang Nomor 23 Tahun 2002 Tentang Perlindungan Anak (Lembaran Negara Republik Indonesia Tahun 2014 Nomor 297, Tambahan Lembaran Negara Republik Indonesia Nomor 5606).

Putusan Pengadilan Negeri Kolaka Nomor 284/Pid.Sus/2017/PN.Kka.

Surat Edaran Mahkamah Agung Republik Indonesia Nomor 1 Tahun 2017 tentang Pemberlakuan Rumusan Hasil Rapat Pleno Kamar Mahkamah Agung Tahun 2017. 